See discussions, stats, and author profiles for this publication at: https://www.researchgate.net/publication/281743214

\title{
Dictators in Exile: Explaining the Destinations of Ex-Rulers
}

Research · September 2015

2 authors, including:

6. Abel Escribà-Folch

1.) University Pompeu Fabra

45 PUBLICATIONS 796 CITATIONS

SEE PROFILE

Some of the authors of this publication are also working on these related projects:

Migration and Democracy: How Remittances Undermine Dictatorships View project 


\title{
Dictators in Exile: Explaining the Destinations of Ex-Rulers
}

\author{
Abel Escribà-Folch* $\quad$ Daniel Krcmaric ${ }^{\dagger}$
}

\section{Forthcoming in the Journal of Politics}

\begin{abstract}
Exile has been the second most common fate for dictators who lost office since World War II, yet scholars know little about this phenomenon. In this article, we ask a simple yet previously unanswered question: where do exiled dictators go? We argue that three sets of factors - transnational ties, geographic proximity, and monadic characteristics of potential host states - influence where dictators flee. For evidence, we use original data on exile destinations to construct a directed dyadic dataset of all autocratic rulers who fled abroad upon their ouster. We find that dictators are more likely to go into exile in states that are close neighbors, have hosted other dictators in the past, are militarily powerful, and possess colonial links, formal alliances, and economic ties. By contrast, fleeing dictators tend to avoid democratic states and countries experiencing civil conflict. These findings raise broader implications for several outcomes ranging from regime transitions to conflict termination.
\end{abstract}

Keywords: dictators, exile, post-tenure fate

*Abel Escribà-Folch (abel.escriba@upf.edu) is an associate professor in the Department of Political and Social Sciences at the Universitat Pompeu Fabra, Barcelona, Spain.

$\dagger$ Daniel Krcmaric (daniel.krcmaric@northwestern.edu) is an assistant professor in the Department of Political Science at Northwestern University, Evanston, IL, 60208. 
Losing power is dangerous for dictators. When their time in office comes to an end, they face a higher risk of punishment such as death or imprisonment than democratic leaders (e.g., Goemans 2008). Not surprisingly, then, one of the most common post-tenure fates for dictators has been exile. When coups, revolutions, or civil wars threaten dictators, they often rush out of their countries looking for protection abroad. In fact, exile has been the second most common fate for outgoing dictators in the post-World War II era: 20.1\% (98 leaders) fled their countries after losing office during this period. ${ }^{1}$

Though rarely studied in detail by political scientists, exile is an important topic that touches on several other outcomes of interest such as democratization, war termination, and human rights. For example, exile has facilitated political change and conflict resolution in a number of instances. When Ugandan rebels and Tanzanian troops marched on Kampala in 1979, Ugandan dictator Idi Amin fled into exile in Libya (and later settled in Saudi Arabia) rather than escalate the war. With American assistance, Ferdinand Marcos went into exile in Hawaii after the People Power Revolution toppled him in 1986. In the same year, Haiti's Jean-Claude Duvalier was able to settle in the south of France after a popular uprising overthrew him. In all three cases, the availability of a safe exile destination for the outgoing dictator arguably made the regime transition smoother than it otherwise might have been.

By contrast, when leaders are unable to find an exile destination that provides credible protection, they may have incentives to cling to power at all costs rather than flee abroad. During the 2011 Libyan conflict, Muammar Gaddafi-who faced an International Criminal Court indictment - opted to fight to the death rather than go into exile. ${ }^{2}$ Some speculate

\footnotetext{
${ }^{1}$ This figure is obtained using the Archigos dataset of leaders (Goemans et al. 2009), which codes leaders' post-tenure fates, and Geddes et al.'s (2014) authoritarian regimes data. In terms of other post-tenure fates for dictators over 1946-2012, 45.7\% stayed in their country unpunished, $12.3 \%$ were imprisoned, and $8.2 \%$ were executed or assassinated. The remaining $13.7 \%$ of the dictators in the sample died while still in power or left office due to poor health.

${ }^{2}$ Related to Gaddafi's ICC indictment, exile is often seen as a detriment to legal accountability and human rights because it offers dictators a golden parachute. Indeed, escaping to a comfortable retirement abroad can hardly be considered a just outcome for a brutal ruler. In response, international courts have recently attempted to "end impunity" by prosecuting exiled leaders. We explore the implications of this
} 
that Gaddafi's decision was based, among other things, on the inability to find a country willing and able to grant him long-term protection. ${ }^{3}$ More recently, efforts to coax Syria's Bashar al-Assad out of power with an international retirement have failed as well. As British leader David Cameron put it, "I am certainly not offering [Assad] an exit plan to Britain. But if he wants to leave, he could leave; that could be arranged." ${ }^{4}$ Yet one important question remained unanswered: where, exactly, would Assad retire?

These examples raise broader questions. Where do exiled leaders go? And why are some foreign countries more willing and better able to offer credible protection to ousted rulers? In this paper, we shed light on these issues by analyzing the factors that influence the destinations of fleeing dictators. ${ }^{5}$ Our argument focuses on three general factors: the extent of transnational ties, the geographical distance between countries, and the monadic characteristics of potential host states. Using original data on exile destinations for all autocratic rulers who fled abroad upon their ouster for the period 1946-2012, we find support for our claims. Dictators are more likely to go into exile in states that are geographically proximate, have hosted other exiled dictators in the past, are militarily powerful, and possess colonial links, formal alliances, and economic ties. By contrast, fleeing dictators tend to avoid democratic states and countries experiencing civil conflict. These results raise major implications for political scientists because the availability of viable exile destinations determines whether retiring abroad is an attractive option for leaders, which in turn affects whether they have incentives to cling to power or step down peacefully.

"justice cascade" (Sikkink 2011) on the use of exile later in the article.

${ }^{3}$ Jackson Diehl, "After the Dictators Fall," Washington Post, 5 June 2011; Barbara Walter, "Why Didn't Qaddafi Go into Exile?" Washington Post, 25 October 2011.

${ }^{4}$ Mohammed Abbas and Khaled Yacoub Oweis, "Bombings Rock Damascus, Brother of Parliament Speaker Killed," Reuters, 6 November 2012.

${ }^{5}$ We also discuss the relationship between where to flee and whether to flee later in the paper. In short, exile occurs when two conditions are present. First, dictators must have a reason to consider fleeing abroad, such as domestic unrest and/or institutional weaknesses that hinder their ability to obtain credible domestic exit guarantees. Second, for exile to be an attractive option, dictators must find a host state willing and able to provide protection. Our paper focuses on the latter part, though we also consider the former part briefly (see the selection model in the appendix). 
The remainder of this article is structured as follows. The next section highlights the importance of exile and identifies the factors affecting dictators' exile destinations. The third describes our exile destinations data and the research design. The fourth presents our results. The fifth discusses the political implications of our findings and explores the possibility of growing obstacles to exile over time. The sixth section concludes.

\section{Theoretical Framework}

\section{Punishment, Protection, and Exile}

Why is a leader's post-tenure fate relevant? As recent research highlights, the prospect of post-office punishment influences the behavior of rulers while they are still in power (e.g., Goemans 2008; Anderson 2010; Chiozza and Goemans 2011; Escribà-Folch 2013; Frantz et al. 2014). Indeed, in autocracies, scholars have long argued that the anticipation of a bad post-office fate makes dictators less likely to step down peacefully and negotiate a regime transition. ${ }^{6}$ Unless autocrats can extract credible exit guarantees that their interests and safety will be protected after the transition, rulers have incentives to entrench in power and refuse to resign (Dix 1982; O'Donnell and Schmitter 1986; Sutter 1995). This is caused by time-inconsistency problems associated with transition pacts that grant immunity to outgoing elites (Huntington 1991; Przeworski 1991; Geddes 1999). Once the ruler has stepped down, the new authorities have incentives to renege on the agreement and punish him.

Of course, this is not meant to imply that negotiated transitions are impossible. Peaceful transfers of power are feasible if credible domestic exit guarantees to outgoing elites are offered in the form of explicit or tacit immunity agreements. The credibility of such pacts may vary across autocratic regime type. Military and party-based regimes possess institu-

\footnotetext{
${ }^{6}$ Similar dynamics may occur in democracies as well. Baturo (2014) shows that immunity guarantees and a low value of political office increase the likelihood that elected rulers comply with term limits.
} 
tionalized mechanisms for retaining some domestic leverage even after democratization and are thus more likely to end in negotiated transitions: the former can threaten to stage a coup while the latter can compete in subsequent elections (Huntington 1991; Sutter 1995; Geddes 1999; Wright and Escribà-Folch 2012; Albertus and Menaldo 2014). Yet, stepping down from power in an autocratic state - even one where exit guarantees are relatively more credible - almost always carries risk for a leader since circumstances can change quickly after leaving power. ${ }^{7}$ Hence, dictators often have a compelling reason to resist political change.

This dynamic - dictators having incentives to cling to power in order to avoid punishmentinfluences several outcomes beyond regime transitions. For example, the prospects of leader survival and subsequent punishment affect the initiation, duration, and outcome of international conflicts (Bueno de Mesquita and Siverson 1995; Goemans 2000; Chiozza and Goemans 2011; Debs and Goemans 2010; Croco 2011; Weeks 2014) primarily by creating incentives for leaders to "gamble for resurrection." Moreover, the desire of rulers to avoid punishment also shapes repression and civil conflict. If leaders think making peace will result in some sort of punishment, they have an incentive to keep fighting. This, in turn, may produce human rights violations (Frantz et al. 2014) and protracted civil wars (Goldsmith and Krasner 2003; Snyder and Vinjamuri 2004; Krcmaric 2016).

Therefore, the threat of post-tenure punishment shapes the behavior of leaders while they are still in office across several dimensions. This punishment dilemma, however, can be alleviated through a mechanism other than immunity pacts. Dictators unable to obtain domestic guarantees may go into exile and obtain foreign protection. Indeed, exile can be an attractive option because it helps overcome the commitment problem associated with giving up power. As described earlier, a leader has no motive to step down if he expects the opposition to settle old scores. While it is often difficult for the opposition to create an exit

\footnotetext{
${ }^{7}$ For example, Hosni Mubarak of Egypt (who headed a regime with a powerful military and reasonably strong party) stepped down in 2011 with plans to retire to the resort town of Sharm el-Sheikh, but he was instead put on trial by the successor regime.
} 
guarantee that protects the ruler from post-tenure punishment, exile mitigates this problem. When a leader flees abroad, he no longer needs to fear retribution since he is outside the grasp of his old adversaries. ${ }^{8}$

This logic suggests that exile - despite its association with unpleasant dictators enjoying golden retirements abroad - can be politically useful. External exit options may provide incentives for rulers, particularly those facing domestic unrest, to step down and leave the country. Indeed, most dictators who went into exile did so in the midst of a coup, revolt, or civil war, and were thus at risk of retribution. ${ }^{9}$ In this sense, exile is a substitute for domestic safety that allows "bad" rulers to avoid the costs of losing power. This, in turn, can pave the way for conflict resolution and democratization by reducing the ruler's motivation to cling to power. $^{10}$

As a result, foreign governments often have incentives to accept dictators' asylum requests or to help them find a host country (Gilligan 2006). In addition to facilitating conflict termination or regime change, there are several other reasons why a state might host an exiled dictator. Doing so can be an effective way to signal to other friendly leaders that they will be protected if necessary, keep a close eye on troublesome ex-rulers, defuse escalating political tensions in an ally or trading partner, and manage regional instability. A quick glance at the historical record seems consistent with this logic: there traditionally has been no shortage of third-party states willing to host fleeing dictators. ${ }^{11}$

At the same time, however, hosting an exiled ruler can be costly. Sheltering a dictator,

\footnotetext{
${ }^{8}$ Of course, exile is never a perfectly credible solution for the leader because it is possible that he will be prosecuted or extradited. However, dictators still have incentives to go into exile if the perceived risks of punishment abroad are lower than the risks of domestic punishment. For leaders facing domestic unrest or political instability, this is usually the case.

${ }^{9}$ Approximately $84 \%$ of exiled dictators faced at least one of these forms of domestic unrest at the time of their departures.

${ }^{10}$ Models of democratization often assume the value of losing power is zero, but our argument implies this is not necessarily true. When an attractive exile option exists, an autocratic leader's payoff to giving up power may be greater than zero.

${ }^{11}$ Recall that exile has been the second most common fate for dictators who lost office since 1945 .
} 
especially an unpopular one, may carry domestic public opinion costs, complicate diplomatic relations with the successor government in the dictator's home state, and trigger international pressure to extradite or prosecute the leader. ${ }^{12}$ Moreover, some states may be reluctant to host an ousted dictator because, for reasons of geography or history, they simply have little at stake in the dictator's home country. In line with this view, a number of ex-dictators have been denied entry in foreign countries (or were asked to leave shortly after arriving), and many countries have never served as exile destinations. For instance, former Zairian dictator Mobutu was denied asylum by France. Almost caught by the opposition, Mobutu and his entourage then rushed out of Zaire and went into exile in Togo. However, Togo asked Mobutu to leave only a few days later, and he eventually settled in Morocco. ${ }^{13}$ As this example suggests, not all countries are equally willing to shelter dictators in exile.

This discussion of the potential host state's perspective informs our argument about where ousted dictators flee. Simply put, host state preferences shape the choices dictators make. Therefore, in the next section, we elaborate on the conditions under which potential host states have particularly strong or weak incentives to shelter outgoing rulers. Dictators, in turn, develop assessments of the likelihood of protection in possible exile locations and select their destination accordingly. Anticipating that some states are more willing and better able to offer protection, ousted dictators will opt to settle in some places over others.

\section{Explaining Destination Availability and Choice}

We develop a novel theoretical framework for understanding exile destinations by exploring three sets of factors. First, transnational connections between states - such as political, economic, and historical ties - affect the incentives foreign countries have to grant asylum to

\footnotetext{
${ }^{12}$ For example, the hostage crisis at the American Embassy in Iran (1979-1981) was the result of protests demanding, among other things, the Shah's extradition.

${ }^{13}$ Howard W. French, "Mobutu Sese Seko, Zairian Ruler, Is Dead in Exile in Morocco at 66," New York Times, 8 September 1997.
} 
fleeing dictators. Second, the geographic distance between countries shapes both host state incentives and leader opportunities for exile, which is especially relevant in situations where dictators must rush out of their countries amid turmoil. Third, the monadic characteristics of potential host states influence their ability to provide credible protection. The first two factors capture dyadic characteristics (bilateral relations and distance), while the third stresses the characteristics of the host state itself.

Dyadic Ties. The first factor is the extent of transnational ties. Dictators are more likely to flee to countries with which they have deep historical, political, military, or economic links. Existing ties between countries help define the subset of states that are likely to have strong incentives to host a fleeing dictator. For example, former colonies usually became allies of their metropolis and kept extensive political and economic ties after independence. Indeed, most former colonial powers have remained profoundly involved in the domestic politics of their former colonies, with dictators often being instrumental to the protection of ex-colonizers' interests. The same is true for countries with strategic alliances, especially during the height of the Cold War. ${ }^{14}$ Superpowers and former colonial powers have used foreign policy instruments such as economic aid and military interventions to prop up friendly leaders - including numerous autocrats - and to extract policy concessions (e.g., Alesina and Dollar 2000; Bueno de Mesquita and Smith 2009; Kono and Montinola 2009; Bermeo 2011; Berger et al. 2013).

There are several reasons why transnational linkages may give countries incentives to host and protect outgoing rulers. On the one hand, granting asylum can be a way to reward a friendly ruler in trouble by offering him a safe haven for retirement. Moreover, by doing so, a state can signal to other friendly leaders that they too will be protected, which further incentivizes them to align with the host state's foreign policy interests. For

\footnotetext{
${ }^{14}$ For instance, all dictators who settled in the US (as their primary destination) did so during the Cold War.
} 
instance, France maintained multiple economic and political interests in post-colonial Africa. Ahmadou Ahidjo, Cameroon's first President (1960-1982), was installed in power by the French and was considered a close political and economic ally (Atangana 2010). When a power struggle broke out between Ahidjo and his successor, Paul Biya, Ahidjo sought protection abroad, and France agreed to host him.

On the other hand, by offering an exit option, foreign countries can defuse a potentially destabilizing political situation that would harm the interests of the former colonial ruler or ally. Consider the Philippines under Ferdinand Marcos. The Philippines was a former US colony, and Marcos was a key anticommunist ally who received generous economic and military support (Thompson 1998). In 1986, the People Power Revolution challenged Marcos after a rigged election. Amidst growing unrest and a failed military coup, the US helped convince Marcos to step down. Marcos accepted an offer of asylum from President Reagan, ${ }^{15}$ making possible a peaceful transition of power to the moderate opposition headed by Corazon Aquino (Snyder 1992).

Some countries even host former rulers so they can keep a close eye on them and ensure they stay out of politics. This may allow for a friendlier leader to take over without violence and can prevent former leaders from trying to regain power, thus triggering further instability. For instance, the USSR forced Hungary's Stalinist leader Mátyás Rákosi to resign in 1956 as his growing unpopularity increased the risk of a regime failure that would threaten Soviet interests in the region. At the Soviet leadership's command, Rákosi went into exile in the USSR (where he remained until his death in 1971) so that he could no longer interfere in Hungarian politics.

Geographic Proximity. The second factor is geographic proximity. Physical distance can be an important factor in explaining exile destinations for two complementary reasons. First, physical distance between countries affects fleeing dictators' decisions on where to

\footnotetext{
${ }^{15}$ In fact, Marcos was flown out of the Philippines on a US military aircraft, which took him to Hawaii.
} 
go by shaping opportunity. Dictators are often toppled by unforeseen events that unfold rapidly such as coups and mass uprisings. When rulers must rush out of their countries to avoid being captured or killed by rivals, escaping a nasty fate is often a matter of time. Geographically proximate countries make attractive destinations because they are easier to access by air or even by land. ${ }^{16}$ For example, as his regime crumbled in 2014, Burkina Faso's Blaise Compaoré quickly drove in an armed convoy to the border with the Ivory Coast, where a helicopter then airlifted him and his family to safety. Other dictators are less fortunate: former Romanian leader Nicolae Ceaucescu was captured while attempting to escape first by helicopter and then by car. After a show trial, he was executed by firing squad. ${ }^{17}$

Second, distance also shapes a foreign state's willingness to host a dictator in exile. Neighboring countries should have stronger incentives to grant asylum to an outgoing ruler because they are more likely to suffer negative externalities - such as refugee flows or political instability - that can spread across borders (e.g., Salehyan and Gleditsch 2006; Gleditsch 2007; Krcmaric 2014). For example, Michel Djotodia fled the Central African Republic for Benin in 2014 amid escalating sectarian violence. Benin's foreign minister stated, "Benin accepts to welcome him at the request of member states of the Economic Community of Central African States and it is our contribution to the search for peace in central Africa." 18 Thus, granting asylum to a neighboring ex-dictator can be a calculated strategy to reduce regional instability.

Monadic Characteristics of Potential Hosts. The monadic characteristics of potential host states represent the third factor in our theory. As mentioned earlier, dictators

\footnotetext{
${ }^{16}$ Some fleeing dictators may also prefer to settle in neighboring countries since this gives them the opportunity to establish a "base of operations" from where they might try to regain power. For example, after being ousted by Idi Amin in 1971, Uganda's Milton Obote settled in neighboring Tanzania. From there, Obote denounced Amin and organized an armed opposition against his regime. In 1979 Tanzanian troops, joined by Obote's Ugandan exiles, invaded Uganda and deposed Amin. Obote became President again in 1980 .

${ }^{17}$ Clyde Haberman, "Pilot of Helicopter Describes Ceausescu's Escape Attempt," New York Times, 1 January 1990.

18 "CAR Ex-leader Heads for Exile in Benin," Al Jazeera, 12 January 2014.
} 
have good reasons to develop assessments of the risk of punishment or extradition in potential exile locations. If possible, they would rather settle in countries that not only offer to host them but also provide credible long-term protection. The characteristics of potential host states are relevant because they enhance or constrain states' ability to offer credible protection to fleeing rulers. These characteristics, in turn, affect dictators' exile choices. Several testable implications are described below.

To start, fleeing autocrats are more likely to go to countries that have previously hosted another dictator. States that have sheltered exiled rulers before should look more attractive to a current leader deciding where to flee as this signals that the state is willing and able to provide protection.

Another implication is that ex-dictators are unlikely to settle in countries where policy reversals regarding their status are likely. Two characteristics of potential host countries are relevant for dictators' risk assessments of policy reversals. First, ex-dictators should prefer to settle in major powers because such states are strong enough to resist international pressure to extradite or prosecute the leader. ${ }^{19}$ Second, ex-dictators should prefer countries with stable political regimes. We expect ex-rulers will avoid settling in countries experiencing violent conflict, which may jeopardize their security or result in the overthrow of the host state's leadership that initially offered protection. Since the promises made by one government may not be honored by the next one, political instability should undermine a dictator's assessment of long-term safety.

The regime type of potential host states may also play a role when dictators assess the credibility of protection. We predict that ousted dictators will be unlikely to seek asylum

\footnotetext{
${ }^{19}$ Several of the examples mentioned throughout the article support this point. Consider how Charles Taylor and Hissène Habré were eventually prosecuted after going into exile in relatively weak states (Nigeria and Senegal, respectively). The counterfactual is that a major power would have been better able to resist international pressure (such as when the US protected the Shah of Iran despite pressure to extradite him). Moreover, major powers tend to be exile destinations for an additional reason: major powers have global interests, giving them particularly strong incentives to host outgoing rulers for the reasons already identified.
} 
in democratic countries. Democracies typically have a deeper commitment to human rights and the rule of law, ${ }^{20}$ which could be especially relevant when an ex-dictator's home state or an international court expresses interest in prosecuting the leader. In such cases, democracies may decline to host a fleeing autocrat or may later decide to extradite a leader they initially accepted. Additionally, democracies should face higher public opinion costs for hosting dictators, particularly when they have an unsavory personal history. ${ }^{21}$ The case of former Chadian dictator Hissène Habré's exile in Senegal, often considered one of Africa's model democracies, is illustrative. Habré fled to Senegal in 1990 (when it was still a party-based autocracy) and initially enjoyed a quiet retirement. However, his stay there became increasingly precarious - especially after Senegal democratized in 2000-as human rights groups uncovered and publicized evidence showing that Habré's regime routinely engaged in gross human rights violations and ethnic killings. Facing a domestic public that did not want to shelter a brutal dictator and an international community that sought to bring Habré to justice, the Senegalese government eventually arrested Habré in order to try him at the Extraordinary African Chambers.

Finally, we expect dictators are less likely to settle in countries that have a deep commitment to international human rights. In fact, the development of an international human rights regime centered on individual criminal accountability (e.g., Sikkink 2011; HafnerBurton 2013) may complicate the exile option. Participation in the global accountability regime, such as previously holding human rights trials or joining the International Criminal Court (ICC), should make a state an unlikely exile destination by signaling the country's commitment to justice and human rights. ${ }^{22}$ Fleeing dictators - a subset of leaders especially likely to have presided over human rights violations while in power - may be unlikely to re-

\footnotetext{
${ }^{20}$ O'Donnell 2004.

${ }^{21}$ Later in the paper, we explore whether dictators with violent histories (e.g., those who presided over state-sponsored mass killings) are especially unlikely to go into exile in democracies.

${ }^{22}$ Moreover, member states are legally obliged to arrest and extradite individuals indicted by the ICC, making it difficult for such states to offer credible protection (Ginsburg 2009).
} 
ceive asylum in such countries. Even if an offer of protection is given, it will lack credibility over the long-term if the dictator believes the state will eventually prosecute or extradite him. Therefore, we anticipate that fleeing dictators are unlikely to be accepted in ICC members or states with a history of human rights trials. ${ }^{23}$

In sum, our theoretical discussion generates the following hypotheses:

- Dyadic Ties Hypothesis: Fleeing dictators are more likely to go to countries with trade, alliance, or colonial ties.

- Distance Hypothesis: Fleeing dictators are more likely to seek refuge in geographically proximate countries.

- Monadic Characteristics Hypothesis: Fleeing dictators are less likely to go to countries with ongoing conflicts, democratic regimes, or commitments to international human rights law. Fleeing dictators are more likely to settle in countries that are major powers or have previously hosted an exiled dictator.

\section{Data and Research Design}

To test our hypotheses, we collected original data on the destinations of dictators who went into exile during the period 1946-2012. ${ }^{24}$ We focus on the country where fleeing dictators

\footnotetext{
${ }^{23}$ The Muammar Gaddafi example mentioned in the introduction hints at several of the monadic characteristics of potential hosts stressed above: ICC membership, democracy, and political instability. For example, one discussion of Gaddafi's exile options noted: "The trouble is, Africa's so-called "king of kings" doesn't have many choices. Gaddafi's brutal treatment of Libyan citizens would make him an unwelcome house guest for any country that wants to have a semblance of a relationship with the United States or much of Europe...Thirty-one African countries have signed on to the International Criminal Court, which probably would put Gaddafi at too much risk of ending up at The Hague. And most of his fellow Arab autocrats are hardly in a position to offer anyone a safe haven these days. Plus, if he chose a regime in his own back yard, there would be a fairly good chance he'd have to flee again." See William J. Dobson, "Dictator Seeks Second Home? A Guide to Gaddafi's Exile Options," Washington Post, 29 March 2011.

${ }^{24}$ We identified individual leaders and their post-exit fates using Archigos (Goemans et al. 2009) and authoritarian regimes using Geddes et al. (2014). Our sample of exiled dictators includes all autocratic rulers who were the effective heads of their countries on January 1st and went into exile within one year of their ouster. We collected data on exile destinations from a number of sources, including newspaper articles (local and international), Lentz (1994), case studies and secondary scholarly accounts, Archigos, Keesing's, etc. We also consulted country experts when no reliable information could be found. Note that Anastasio Somoza Debayle is included in the sample even though his post-exit fate is coded as "death" in Archigos. Archigos codes Debayle this way because he was assassinated in exile in Paraguay within the first year of losing power.
} 
settled, since our interest is in identifying the countries that are willing and able to offer longterm protection. Hence, the countries (if any) where ex-rulers stopped very briefly on their way to their primary destination are not included. ${ }^{25}$ If a leader settled in multiple countries, however, these additional destinations are also coded and are used as a robustness check in the appendix. ${ }^{26}$ Figure 1 employs data on the 98 dictators who went into exile in the period under study and visually represents the number of ex-rulers each country hosted. ${ }^{27}$ The results indicate that 52 countries have hosted at least one dictator. The leading destinations include the US with eleven exiled dictators, the USSR/Russia and the UK with seven each, Argentina with six, and France with five. ${ }^{28}$

(Figure 1 here)

We then used our data on exile destinations to create a dataset of directed dyads for all cases in which an autocrat lost power and fled abroad. In other words, given that a fleeing dictator could potentially go to any other country in the world, each case of exile is paired with all other countries in the state system to create an exhaustive set of possible exile destinations. The dyadic nature of the dataset allows us to capture characteristics of the dictator's country of origin (State A), all potential destinations (State B), and the connections between State A and State B. Our full dataset includes the 98 autocrats who went into exile over the period 1946-2012, but due to data limitations for some of the independent variables, the period covered in most of the multivariate analyses is 1946-2008 (during which

\footnotetext{
${ }^{25}$ For instance, some dictators made brief stops in foreign countries for idiosyncratic reasons such as refueling a plane or receiving medical treatment. These short stays are not included.

${ }^{26}$ The full list of exiled dictators and their destinations can be found in the appendix.

${ }^{27}$ Figure 1 shows both the primary destination and additional destinations (if any). For example, Cuba's Fulgencio Batista spent most of his exile in Portugal but later moved to Spain (where he died in 1973). Both countries are listed as having hosted Batista in Figure 1.

${ }^{28}$ The fact that several of the leading destinations are Western democracies (e.g., the US, the UK, and France) may seem to contradict our prediction that democracy reduces a state's appeal as an exile destination. However, these same Western democracies also tend to be major powers, have extensive post-colonial ties, and possess large alliance portfolios. It is only after controlling for these factors that we expect fleeing dictators to be less likely to seek exile in democracies. We explore this later in the paper.
} 
95 dictators went into exile). ${ }^{29}$ The dependent variable is a dichotomous indicator for whether a dictator from State A went into exile in State B in a given year. Given the binary nature of the exile variable, the models are estimated using logistic regression with standard errors clustered on the country of origin.

One might critique this research design by arguing that the decision on whether to go into exile precedes the decision on where to go into exile, thereby requiring a two-stage selection model. While dictators certainly make decisions on both whether and where to flee, the decision to flee abroad is not necessarily prior to the decision on where to go. If anything, the opposite may be true: leaders are likely to reject the exile option precisely because they cannot identify a suitable destination that provides credible protection. Moreover, the factors "pushing" leaders to consider exile (e.g., civil war in a leader's home country) are not the same factors "pulling" leaders to one exile destination instead of another (e.g., the variables identified in our theory). Given this, it seems unlikely that a selection model is warranted. Nonetheless, it remains possible that some omitted factor could influence both whether dictators seek exile and where they flee. Therefore, as a robustness check, we estimate a selection model (see appendix) and find that the results are consistent with those reported in the main text..$^{30}$

Moving on to the main analysis, one set of independent variables reflects the nature of the relationship between State A and State B, allowing us to test our first hypothesis on transnational ties. To measure economic connections between states, we use the Correlates

\footnotetext{
${ }^{29}$ The three leaders excluded because they went into exile after 2008 are: Dadis Camara (Guinea 2009), who went to Burkina Faso; Ben Ali (Tunisia 2011), who went to Saudi Arabia; and Bakiyev (Kyrgyzstan 2010), who went to Belarus. Bin Taimur (Oman), who was ousted in 1970 and went to the UK (Oman's former colonial power), is also excluded because Oman only enters the COW state system in 1971. Najibullah (Afghanistan) is included although he did not go into exile in another country but instead took refuge in 1992 in a United Nations compound in Kabul for four years. The sample used may vary slightly due to the different periods covered by some of the independent variables.

${ }^{30}$ The selection model is complex since the two stages are observed at different units of analysis. Specifically, the first stage examines all leader years, whereas the second stage examines directed dyads for the subset of leaders who went into exile. See the appendix for a detailed description.
} 
of War (COW) trade flows data, which measure import and export data in current US millions of dollars for pairs of states (Barbieri and Keshk 2012). ${ }^{31}$ To account for former colonial relationships between states, we use a dummy that equals 1 if State A was a colony of State B and 0 otherwise. Colonial origin data are from Hadenius and Teorell (2007) and Hensel (2014). ${ }^{32}$ To capture geostrategic bilateral relationships between states, we use data on alliances from the COW Formal Alliances (Gibler and Sarkees 2004; Gibler 2009) and the Alliance Treaty Obligations and Provisions (Leeds et al. 2002) datasets. The variable equals 1 if an alliance between State A and State B exists in the year a dictator goes into exile and 0 otherwise.

To test our second hypothesis, we include a variable gauging geographical distance between countries. Distances are measured as the logged number of miles between capital cities (using the "great circle" distance formula). ${ }^{33}$

Another set of variables captures monadic characteristics of potential destinations to test our third hypothesis. As a first proxy for the ability to offer credible protection, we include a dummy variable indicating whether a country has previously hosted a dictator. A second feature is the international status of countries, which we address by including a dummy variable indicating if State B is a major power using COW data. Another important characteristic is regime type. We first distinguish between democracies and dictatorships using Cheibub et al.'s (2010) data. The variable equals 1 if a potential destination (State B) is democratic in the year a dictator goes into exile and 0 if it is a dictatorship. Using Geddes et al.'s (2014) data, we also create dummy variables indicating the type of dictatorship (personalist, party-based, military, and monarchy) of State B. ${ }^{34}$ To model political instability

\footnotetext{
${ }^{31}$ We use the log of the two year moving average of trade interdependence between two countries. The results are almost identical if we use trade interdependence at time $t$.

${ }^{32}$ This variable also includes other domination relationships. Specifically, countries that were part of the USSR and seceded during the fall of the Soviet empire are coded as colonies. There are only three cases in our sample: Georgia, Azerbaijan, and Kyrgyzstan. Excluding them does not change the results.

${ }^{33}$ Distances were computed using EUGene (Bennett and Stam 2000).

${ }^{34}$ Note that the sample is smaller when using Geddes et al.'s (2014) data since it only covers 154 countries
} 
in potential host countries we use two variables: civil war and interstate war. Both are from the UCDP/PRIO Armed Conflict Dataset (Gleditsch et al. 2002) and are dummies indicating if there was an ongoing civil or international conflict in State B in the previous year. Finally, to proxy commitments to the international human rights regime and the global criminal justice system, we use two variables. First, we create a dummy variable for whether State $\mathrm{B}$ ratified the Rome Statute of the International Criminal Court. Second, using data on transitional human rights prosecutions from Kim and Sikkink (2010), we include dummies indicating whether a country had any domestic or international human rights prosecutions. ${ }^{35}$

\section{Results}

Table 1 reports the results of the multivariate models of exile destinations using our directed dyadic data. Model 1 includes the variables capturing historical and political connections (Hypothesis 1) and the measure of distance between countries (Hypothesis 2). Model 2 adds the variable gauging trade interdependence, which we excluded from the first model because it substantially reduces the number of observations. All four variables are statistically significant in the predicted direction, offering support for our argument. In other words, the results imply that fleeing dictators are more likely to go to the following types of countries: strategic allies, former colonizers, trade partners, and geographically proximate neighbors. ${ }^{36}$

\section{(Table 1 here)}

(namely, those with over one million inhabitants in 2009). For this reason, we used Cheibub et al.'s (2010) data for the simple democracy/dictatorship comparison, which covers 199 countries (namely, all independent regimes since 1946).

${ }^{35}$ The variable equals 1 starting in the first year a prosecution took place and every year thereafter. Using the total number of prosecutions up to year $t$ yields similar results.

${ }^{36} \mathrm{In}$ an interaction model reported in the appendix, we find that the effect of distance is stronger for rulers ousted in coups. This is consistent with our argument since coups are rapid events that rarely give dictators time to plan elaborate escapes. In such cases, fleeing across the border to a neighboring country is often the best option available. 
In Model 3, we add covariates addressing the monadic characteristics of potential destinations to test Hypothesis 3. As expected, dictators are more likely to seek shelter in states that have hosted a dictator in the past, which should enhance expectations of credible longterm protection. Additionally, fleeing rulers are likely to settle in major powers, as these states are difficult to coerce. ${ }^{37}$ We also find that dictators are significantly less likely to go into exile in countries that are experiencing civil war, whereas the effect of interstate war is negative but not significant. ${ }^{38}$

The results for regime type are especially interesting. Consistent with our prediction, the democracy variable is negative and significant when we control for major power status, colonial relationships, alliances, and bilateral trade, indicating that fleeing dictators are less likely to go to democratic countries. However, if the model is estimated with only regime type and distance as independent variables, the democracy variable becomes positive and significant (see appendix). Taken together, these results suggest that the substantial number of dictators going into exile in a handful of Western democracies (primarily the US, the UK, and France) is likely due to their status as allies, major powers, former colonizers, and trade partners rather than their democratic political systems. ${ }^{39}$

The results regarding human rights and international legal accountability are mixed. We find that dictators are less likely to go to countries that are members of the ICC, but the

\footnotetext{
${ }^{37}$ Estimating a model using COW's National Material Capabilities Index (Singer 1987) instead of the "major power" dummy produces similar results. Further, using an interaction model, we find that leaders are more likely to settle in major powers if they are also allies (see appendix). The effect of major power status without an alliance, however, remains positive and significant.

${ }^{38}$ We also examine other measures of instability: the (lagged and logged) sum of riots, strikes and antiregime demonstrations (Banks and Wilson 2013) and a variable indicating if a country has experienced a successful coup in the past three years (Powell and Thyne 2011). These variables are both insignificant (see appendix), suggesting that dictators take into account only high-intensity internal conflict when choosing exile destinations.

${ }^{39}$ We further explore the role of regime type by investigating whether "bad" rulers are reluctant to seek refuge in democracies. Specifically, the results of an interaction model show that dictators who presided over state-sponsored mass killings are significantly less likely to go into exile in democracies (see appendix). This is consistent with our prediction that democracies are reluctant to host dictators due to public opinion costs and their commitment to human rights and the rule of law.
} 
coefficient is not significant. This might be explained by the ICC's paucity of indictments, its lack of enforcement capacity, and the limited time frame since the creation of the court and the end of our sample. ${ }^{40}$ In the appendix, we also test whether a history of human rights prosecutions in State B influences ex-dictators' risk assessments. The variable indicating if a potential host country previously had an international prosecution is automatically dropped from the model since it predicts failure perfectly, revealing that no dictator has gone into exile in a country with prosecutions conducted by international tribunals. ${ }^{41}$ Yet, the coefficient for domestic human rights prosecutions in State B is insignificant.

The last model includes data on the regime type of potential destinations using Geddes et al.'s (2014) classification of authoritarian regimes. This data allow us to disaggregate autocratic regime type beyond the autocracy/democracy comparison used previously and explore whether certain types of autocracies make more attractive exile destinations than others. ${ }^{42}$ Building on our logic regarding the ability to offer credible long-term protection, we expect personalist regimes will be unlikely destinations for fleeing dictators because these regimes are internationally weak and thus vulnerable to foreign pressure (Escribà-Folch and Wright 2010). ${ }^{43}$ By contrast, other autocratic regimes such as military and party-based regimes should offer relatively more credible protection for ousted rulers. The results in Model 4 are largely consistent with this view: Dictators are less likely to go into exile in

\footnotetext{
${ }^{40}$ If only the post-1997 period is used (the Rome Statute of the ICC opened for signature in 1998), the ICC dummy remains negative but insignificant (see appendix).

${ }^{41}$ These results should be interpreted with caution due to the limited number of countries with international prosecutions and the limited time period covered by the prosecutions data. For these reasons, we report the models using the Kim and Sikkink (2010) transitional human rights prosecutions data in the appendix.

${ }^{42}$ In the appendix, we also estimate models using a "regime dyads" approach to explore whether fleeing dictators are likely to seek refuge in autocracies similar to the ones they once ruled. The main finding is that military rulers are significantly more likely to go into exile in other military regimes. In a second model, we include some mixed dyads to test if certain types of autocratic rulers are more likely to be granted asylum by democratic governments. The estimated coefficients are not significant for any combination of autocracydemocracy, which indicates that no particular type of autocrat is more likely to be hosted in a democratic country.

${ }^{43}$ Further, personalist regimes should make risky exile destinations because they are normally overthrown violently (Geddes et al. 2014).
} 
personalist regimes (though this variable is not significant) and are significantly more likely to flee to military and party-based autocracies. ${ }^{44}$

Though the results in Table 1 support our theoretical expectations, it is difficult to interpret the magnitude of the effect associated with each covariate because the models are nonlinear. Therefore, we calculate substantive effects that show how changing the value of one independent variable influences the probability of a dictator going into exile in a given country while every other variable is held constant at its median value. ${ }^{45}$ The results, shown in Figure 2, report the first difference and 95\% confidence interval associated with each covariate from Model 3. We find that colonial history has by far the largest effect on the probability of a dictator settling in a given country. Indeed, the results suggest fleeing dictators are nearly 4 percentage points more likely to go to their former colonizers. While this number may not initially seem large, it is quite meaningful once we consider that the baseline likelihood of a ruler going into exile in a particular country is extremely low. ${ }^{46}$ Consistent with our predictions, we also find that alliances, trade interdependence, major power status, and previously hosting other dictators have a positive effect, whereas democracy, civil war, and distance have a negative effect. ${ }^{47}$ However, the means of the first difference estimates for all these variables are less than 1 percentage point, reaffirming that colonial history is the strongest predictor of exile destinations.

(Figure 2 here)

\footnotetext{
${ }^{44}$ The omitted category in this model includes regimes that Geddes et al. (2014) classify as democracies as well as "other" regimes, which includes foreign-occupied, warlord, not-independent, and provisional regimes.

${ }^{45}$ The substantive effects are conducted using Clarify (King, Tomz, and Wittenberg 2000). In the simulations, the dichotomous variables are shifted from 0 to 1 , whereas the continuous variables are shifted from the 25 th percentile to the 75 th percentile.

${ }^{46}$ For this reason, we also reestimate our main models using rare events logistic regression (Tomz, King, and Zeng 2003) and penalized maximum likelihood regression (Firth 1993). We reach similar results (see appendix).

${ }^{47}$ The confidence intervals for interstate war and ICC membership cross zero.
} 


\section{Growing Obstacles to Finding Asylum?}

As argued above, some foreign states have incentives to grant asylum to dictators - especially dictators mired in long-running conflicts - to induce them to step down. Exile historically has provided a golden parachute that almost always ensured the safety of the outgoing dictator. In fact, during the five decades prior to the creation of the ICC, only two dictators in exile were extradited by their host country (Marcos Pérez Jiménez in 1963 and Luis García Meza in 1995). Another dictator, Anastasio Somoza Debayle of Nicaragua, was assassinated during his exile in Paraguay in 1980. This small handful of exceptions, however, only serves to highlight the relative safety of exile. For embattled dictators, going into exile abroad arguably has been the best possible protection against retribution from domestic adversaries.

One reason exile has offered such a credible exit guarantee is that powerful states and international organizations have been profoundly involved in finding host states for outgoing dictators. For example, the US in 1991 helped Ethiopian ruler Mengistu Mariam find asylum in Zimbabwe during the Ethiopian civil war. Hissène Habré left Chad for Senegal in 1990 in an exile allegedly arranged by France. More recently, despite being indicted, Charles Taylor went into exile in Nigeria in 2003 as part of an internationally brokered peace agreement to end Liberia's civil war. Similarly, Michel Djotodia, who left the Central African Republic in 2014, was hosted by Benin at the request of the Economic Community of Central African States.

The international landscape, however, is changing. The development of a globalized human rights regime (e.g., Sikkink 2011; Hafner-Burton 2013) may make exile a less attractive option. Democracies and superpowers appear increasingly reluctant to host outgoing autocrats. $^{48}$ Moreover, the powerful Western states that traditionally have played (and

\footnotetext{
${ }^{48}$ The impact of major power status is smaller and no longer significant if the baseline model (Model 3 of Table 1) includes only the post-Cold War or post-ICC period (see appendix). Also recall that democracies are unlikely to host leaders who presided over state-led mass killings.
} 
sometimes still play) a key role in creating exit plans for dictators are now arguably undermining the credibility of the exile option. For example, two of the dictators mentioned in the previous paragraph - Charles Taylor and Hissène Habré - have recently been extradited to international tribunals because their hosts came under intense Western pressure to pursue legal accountability. The Charles Taylor case is particularly noteworthy because the same Western states that brokered Taylor's exile to Nigeria as part of Liberia's peace agreement later pressured Nigeria to turn Taylor over to the Special Court for Sierra Leone (Tejan-Cole 2009). ${ }^{49}$ Hence, the costs associated with sheltering exiled dictators may be increasing over time. Consequently, the promise of a safe exile abroad may be less credible than it once was, creating commitment problems similar to those typically associated with domestic immunity pacts.

Though we explored this issue tangentially in our main results, we investigate it in more detail here. Recall that our previous results were inconclusive. On the one hand, we found that ICC ratification and prior domestic human rights trials do not have a statistically significant effect on exile destinations. On the other hand, no dictator has ever fled to a state that held an international prosecution.

One possible reason for the seemingly inconsistent results is that our analysis included all dictators over the entire temporal span of the data. We might expect that the effects of legal accountability mechanisms are limited to certain time periods or to a specific subset of leaders. Since the "justice cascade" (Sikkink 2011) is a relatively new phenomenon, we reestimate our baseline model (Model 3 of Table 1) using only the post-Cold War and post-ICC periods. ${ }^{50}$ Additionally, we estimate models limiting our sample to rulers who were ousted

\footnotetext{
${ }^{49}$ Other leaders, such as Alberto Fujimori and Jean-Claude Duvalier, were arrested after leavingsometimes just temporarily - their safe havens. More broadly, the number of former rulers and other state officials prosecuted in domestic and international courts is increasing over time (Lutz and Reiger 2008).

${ }^{50}$ Between 1998 and 2012, nine dictators went into exile. Six fled to former colonial powers or allied countries (Bedie, Vieria, Akayev, Guéi, Sidi Ahmed Taya, and Musharraf). Aristide (Haiti) went to South Africa. Fujimori (Peru), a son of Japanese migrants, fled to Japan, one of Peru's key trade partners. Two recent cases in 2014 (not in our dataset) in Africa left for neighboring countries: Compaoré fled Burkina
} 
by an insurgency/revolt and to rulers who presided over state-sponsored mass killings since these are the cases in which the threat of international justice should be most relevant. Even in these reduced samples, however, we find no evidence that dictators are significantly less likely to flee to ICC members (see appendix). ${ }^{51}$

How should these results be interpreted? One might conclude that, contra our argument, the international human rights regime simply has little effect on the credibility of long-term protection in potential exile destinations. However, we offer two reasons for why such a conclusion may be misguided. First, ICC ratification is an imperfect proxy for how international justice shapes dictators' punishment expectations. Indeed, the ICC's lack of independent enforcement mechanisms means that apprehending leaders is intimately tied to the vagaries of power politics, so a slew of other factors likely shape whether leaders fear the ICC. ${ }^{52}$ Second, the ICC is but one of many international tribunals that can plausibly threaten dictators. In fact, only one leader (the Ivory Coast's Laurent Gbagbo) has been apprehended and transferred to the ICC, while four leaders (Serbia's Slobodan Milosevic, Liberia's Charles Taylor, Cambodia's Khieu Samphan, and Chad's Hissène Habré) have been arrested and sent to other international tribunals. ${ }^{53}$ Therefore, it may make sense to focus on the general trend toward holding leaders accountable rather than ICC ratification specifically.

(Figure 3 here)

To investigate this possibility, Figure 3 shows the rate of dictators going into exile over time. The bars represent the count of dictators fleeing into exile during each period. Since Faso for the Ivory Coast, and Djotodia fled the Central African Republic for Benin.

${ }^{51}$ It is worth emphasizing that the number of observations is drastically reduced in these samples. Also, note that when the sample is limited to leaders involved in mass killings, the effect of the ICC is positive and significant - the opposite of our prediction. However, this result is entirely driven by one case: Charles Taylor going to Nigeria (an ICC member since 2001) in 2003.

${ }^{52}$ The controversy surrounding the recent decision of South Africa (an ICC member) to host - and allegedly help protect-Sudan's Omar Bashir despite an ICC indictment illustrates this point. See Norimitsu Onishi, "Omar al-Bashir, Leaving South Africa, Eludes Arrest Again," New York Times, 15 June 2015.

${ }^{53}$ The specific tribunals are the International Criminal Tribunal for Yugoslavia, the Special Court for Sierra Leone, the Extraordinary Chambers in the Courts of Cambodia, and the Extraordinary African Chambers, respectively. 
the absolute number of dictators going into exile does not capture the fact the number of dictators varies over time, we also graph the percentage of ousted dictators going into exile (the smoothed line). The results suggest that since the late-1990s - precisely when holding heads of state accountable in international courts gained momentum - dictators have in fact been less likely to flee abroad. ${ }^{54}$ Overall, then, there is mixed evidence on whether the recent push for international justice generates new obstacles to finding asylum. ICC ratification itself seems to have little influence on the choice of exile destinations for ousted dictators, but there is a clear downward trend in the number of dictators going into exile in recent years. Ultimately, more time (and therefore observations) will be needed to explore this issue definitively, but the preliminary evidence suggests there may be growing obstacles to exile.

\section{Conclusions}

Where do exiled dictators go? In this article, we developed a new argument about three sets of factors - dyadic connections, geographic proximity, and monadic characteristics of host states - that shape exile destinations. Using an original dataset on the destinations of exiled dictators in the post-World War II era, we found compelling support for most of our predictions.

Understanding the decision calculus of dictators contemplating exile will only become more important over time. In fact, $42 \%$ of the remaining dictatorships today are personalist regimes, the regime type worst positioned to extract credible immunity concessions during domestic transition pacts. ${ }^{55}$ As a result, incentives for embattled dictators to flee abroad to avoid domestic punishment will remain strong. Yet, there is a countervailing pressure.

\footnotetext{
${ }^{54}$ For more on this trend, see Krcmaric 2016. Note that all of the successful indictments and arrests mentioned in the previous paragraph have taken place since 1999. Another key moment for the international justice movement was the arrest of Chile's Augusto Pinochet in the United Kingdom under the principle of universal jurisdiction in 1998.

${ }^{55}$ Consistent with this claim, about $39 \%$ of the exiled dictators in our study were personalist dictators.
} 
The fact that dictators appear less likely to go into exile over time suggests that exile is also becoming increasingly risky due the decreased credibility of foreign protection. If so, sitting dictators will have stronger incentives to cling to power to avoid prosecution, thereby hindering regime transitions and conflict resolution.

For instance, this dynamic is likely occurring in the current Syrian conflict. When Syrian rebels pushed toward Damascus in December 2012, it was widely expected that Syrian leader Bashar Assad would flee abroad. ${ }^{56}$ Assad himself appeared open to this possibility if the circumstances were right and was "looking for a way out" according to one Damascus-based diplomat. ${ }^{57}$ There was a behind-the-scenes diplomatic scramble to find an exile destination for Assad, but a good option never materialized. According to one European Union official, Western countries hoped to find a destination for Assad but also agreed there was "no way we'd have him in our countries." 58 The situation may have been further complicated when US Secretary of State Hillary Clinton labeled Assad a war criminal, perhaps dissuading some states from offering Assad refuge. ${ }^{59}$ Notably, Russia-probably the state best positioned to offer credible long-term protection to Assad according to the factors identified in our theory — did not offer asylum. Without a credible exit option, Assad unsurprisingly decided to continue the conflict, which is still ongoing with over 200,000 lives lost.

As this example suggests, prolonged conflicts and violent regime transitions are likely when policymakers are unable to create viable exit strategies for dictators. Therefore, understanding why some states make more attractive exile destinations than others is both theoretically interesting and policy relevant. Furthermore, bringing the study of exile-

\footnotetext{
${ }^{56}$ Andrew E. Kramer, "In Russia, Exile in Comfort for Leaders Like Assad," New York Times, 28 December 2012.

${ }^{57}$ Anne Barnard and Hwaida Sadd, "No Easy Route if Assad Opts to Go, or to Stay, in Syria," New York Times, 24 December 2012.

${ }^{58}$ Arshad Mohammed and Matt Spetalnick, "U.S. and Allies Exploring Prospects for Assad Exile," Reuters, 2 February 2012.

${ }^{59}$ Richard Spencer, "Bashar al-Assad Could Be Regarded as a War Criminal, Says Clinton," The Telegraph, 28 February 2012.
} 
the second most common fate for outgoing dictators since 1945-into mainstream political science opens exciting new avenues of research. Future work should consider how the availability of exile influences the ruling strategies of leaders. For instance, when rulers know they have a safe haven abroad, they might be more willing to pursue risky or controversial policies while in power, whereas the absence of good exile options might serve as a powerful deterrent against such adventurism. On the flip side, rebels might be emboldened to challenge the status quo whey they anticipate that rulers can find a cushy retirement abroad, but rebels may be reluctant to confront dictators without reliable exit options since such leaders will have incentives to fight to the bitter end. Exploring these topics in greater detail will help create a more complete picture of the complex and multifaceted issues surrounding dictators in exile. 


\section{Acknowledgments}

We thank Svend-Erik Skaaning, Henry Thomson, Joe Wright, the anonymous reviewers, and the JOP editors for helpful comments. We also received useful feedback during earlier

presentations of the paper at WZB (Berlin), the University of Essex, the University of Konstanz, and MPSA 2016. We are grateful to Joseph Sassoon and Roberto Turcios for their assistance with exile destinations data. 


\section{References}

Albertus, Michael, and Victor Menaldo. 2014. "Dealing with Dictators: Negotiated Democratization and the Fate of Outgoing Autocrats." International Studies Quarterly 58(3): 550-565.

Alesina, Alberto and David Dollar. 2000. "Who Gives Foreign Aid to Whom and Why?" Journal of Economic Growth 5(1): 33-63.

Anderson, Lisa. 2010. "The Ex-Presidents." Journal of Democracy 21(2): 64-78.

Atangana, Martin. 2010. The End of French Rule in Cameroon. Lanham, MD: University Press of America.

Banks, Arthur S., and Kenneth A. Wilson. 2013. "Cross-National Time-Series Data Archive." http://www.databanksinternational.com.

Barbieri, Katherine and Omar Keshk. 2012. "Correlates of War Project Trade Data Set Codebook, Version 3.0." http://correlatesofwar.org.

Baturo, Alexander. 2014. Democracy, Dictatorship, and Term Limits. Ann Arbor, MI: Michigan University Press.

Bennett, D. Scott, and Allan C. Stam. 2000. "EUGene: A Conceptual Manual." International Interactions 26(2): 179-204.

Berger, Daniel, Alejandro Corvalan, William Easterly, and Shanker Satyanath. 2013. "Do Superpower Interventions Have Short and Long-term Consequences for Democracy?" Journal of Comparative Economics 41(1): 22-34.

Bermeo, Sarah B. 2011. "Foreign Aid and Regime Change: A Role for Donor Intent." World Development 39(11): 2021-2031.

Bueno de Mesquita, Bruce and Randolph M. Siverson. 1995. "War and the Survival of Political Leaders: A Comparative Study of Regime Types and Political Accountability." American Political Science Review 89(4): 841-855.

Bueno de Mesquita, Bruce and Alastair Smith. 2009. "A Political Economy of Aid." International Organization 63(2): 309-340.

Cheibub, Jose A., Jennifer Gandhi, and James R. Vreeland. 2010. "Democracy and Dictatorship Revisited." Public Choice 143(1-2): 67-101. 
Chiozza, Giacomo and H. E. Goemans. 2011. Leaders and International Conflict. Cambridge, UK: Cambridge University Press.

Croco, Sarah. 2011. "The Decider's Dilemma: Leader Culpability, War Outcomes, and Domestic Punishment." American Political Science Review 105(3): 457-477.

Debs, Alexandre and H. E. Goemans. 2010. "Regime Type, the Fate of Leaders, and War." American Political Science Review 104(3): 430-445.

Dix, Robert H. 1982. "The Breakdown of Authoritarian Regimes." The Western Political Quarterly 35(4): 554-573.

Early Warning Project. 2015. "State-led Mass Killing Data Handbook, Version 1.1." http://www.earlywarningproject.com/2015/03/19/data-sources.

Escribà-Folch, Abel. 2013. "Accountable for What? Regime Types, Performance, and the Fate of Outgoing Dictators, 1946-2004." Democratization 20(1): 160-185.

Escribà-Folch, Abel and Joseph Wright. 2010. "Dealing with Tyranny: International Sanctions and the Survival of Authoritarian Rulers." International Studies Quarterly 54(2): 335359 .

Escribà-Folch, Abel and Joseph Wright. 2015. "Human Rights Prosecutions and Autocratic Survival." International Organization 69(2): 343-373.

Firth, David. 1993. "Bias Reduction of Maximum Likelihood Estimates." Biometrika 80(1): $27-38$.

Frantz, Erica, Andrea Kendall-Taylor, and Natasha Ezrow. 2014. "Autocratic Fate: How Leaders' Post-Tenure Expectations Influence the Behavior of Dictatorships." Journal of Diplomacy and International Relations 15(1).

Geddes, Barbara. 1999. "What Do We Know About Democratization After Twenty Years?" Annual Review of Political Science 2: 115-144.

Geddes, Barbara, Joseph Wright, and Erica Frantz. 2014. "Autocratic Breakdown and Regime Transitions: A New Data Set." Perspectives on Politics 12(2): 313-331.

Gibler, Douglas M. 2009. International Military Alliances, 1648-2008. Washington, DC: CQ Press. 
Gibler, Douglas M. and Meredith Reid Sarkees. 2004. "Measuring Alliances: the Correlates of War Formal Interstate Alliance Dataset, 1816-2000." Journal of Peace Research 41(2): 211-222.

Gilligan, Michael J. 2006. "Is Enforcement Necessary for Effectiveness? A Model of the International Criminal Regime." International Organization 60(4), 935-967.

Ginsburg, Tom. 2009. "The Clash of Commitments at the International Criminal Court." Chicago Journal of International Law 9: 499-514.

Gleditsch, Kristian S. 2007. "Transnational Dimensions of Civil War." Journal of Peace Research 44(3): 293-309.

Gleditsch, Nils Petter, Peter Wallensteen, Mikael Eriksson, Margareta Sollenberg, and Havard Strand. 2002. "Armed Conflict 1946-2001: A New Dataset." Journal of Peace Research 39(5): 615-637.

Goemans, H. E. 2000. "Fighting for Survival: The Fate of Leaders and the Duration of Wars." Journal of Conflict Resolution 44(5): 555-579.

Goemans, H. E. 2008. "Which Way Out? The Manner and Consequences of Losing Office." Journal of Conflict Resolution 52(6): 771-794.

Goemans, H. E., Kristian S. Gleditsch, and Giacomo Chiozza. 2009. "Introducing Archigos: A Dataset of Political Leaders." Journal of Peace Research 46(2): 269-283.

Goldsmith, Jack and Stephen D. Krasner. 2003. "The Limits of Idealism." Daedalus 132(1): 47-63.

Hadenius, Axel and Jan Teorell. 2007. "Pathways from Authoritarianism." Journal of Democracy 18(1): 143-157.

Hafner-Burton, Emilie M. 2013. Making Human Rights a Reality. Princeton, NJ: Princeton University Press.

Hensel, Paul R. (2014). "ICOW Colonial History Data Set, Version 1.0." http://www.icow.org/colhist.html.

Huntington, Samuel P. 1991. The Third Wave: Democratization in the Late Twentieth Century. Norman, OK: University of Oklahoma Press.

Kim, Hun Joon and Kathryn Sikkink. 2010. "Explaining the Deterrence Effect of Hu- 
man Rights Prosecutions for Transitional Countries." International Studies Quarterly 54(4): 939-963.

King, Gary, Michael Tomz, and Jason Wittenberg. 2000. "Making the Most of Statistical Analyses: Improving Interpretation and Presentation." American Journal of Political Science 44(2): 347-61.

Kono, Daniel Yuichi, and Gabriella R. Montinola. 2009. "Does Foreign Aid Support Autocrats, Democrats, or Both?" Journal of Politics 71(2): 704-718.

Krcmaric, Daniel. 2014. "Refugee Flows, Ethnic Power Relations, and the Spread of Conflict." Security Studies 23(1): 182-216.

Krcmaric, Daniel. 2016. "Dilemmas of Globalized Justice: International Criminal Accountability, the Exile Option, and Civil Conflict." Presented at the Annual Meeting of the Midwest Political Science Association, Chicago, IL.

Leeds, Brett Ashley, Jeffrey M. Ritter, Sara McLaughlin Mitchell, and Andrew G. Long. 2002. "Alliance Treaty Obligations and Provisions, 1815-1944." International Interactions 28(3): 237-260.

Lentz, Harris M. 1994. Heads of States and Governments: A Worldwide Encyclopedia of Over 2,300 Leaders, 1945 through 1992. Jefferson, NC: McFarland.

Lutz, Ellen L. and Caitlin Reiger (eds.). 2009. Prosecuting Heads of State. Cambridge, UK: Cambridge University Press.

O'Donnell, Guillermo and Philippe Schmitter. 1986. Transitions from Authoritarian Rule: Tentative Conclusions about Uncertain Democracies. Baltimore, MD: The Johns Hopkins University Press.

O’Donnell, Guillermo. 2004. "Why the Rule of Law Matters." Journal of Democracy 15(4): 32-46.

Powell, Jonathan and Clayton Thyne. 2011. "Global Instances of Coups from 1950-Present." Journal of Peace Research 48(2): 249-259.

Przeworski, Adam. 1991. Democracy and the Market. Political and Economic Reforms in Eastern Europe and Latin America. New York, NY: Cambridge University Press.

Salehyan, Idean and Kristian S. Gleditsch. 2006. "Refugees and the Spread of Civil War." International Organization 60(2): 335-366. 
Sikkink, Kathryn. 2011. The Justice Cascade: How Human Rights Prosecutions Are Changing World Politics. New York, NY: Norton.

Singer, J. David. 1987. "Reconstructing the Correlates of War Dataset on Material Capabilities of States, 1816-1985." International Interactions 14(2): 115-32.

Snyder, Jack, and Leslie Vinjamuri. 2004. "Trials and Errors: Principle and Pragmatism in Strategies of International Justice." International Security 28(3): 5-44.

Snyder, Richard. 1992. "Explaining Transitions from Neopartimonial Dictatorships." Comparative Politics 24(4): 379-399.

Sutter, Daniel. 1995. "Setting Old Scores: Potholes along the Transition from Authoritarian Rule." Journal of Conflict Resolution 39(1): 110-128.

Tejan-Cole, Abdul. 2009. "A Big Man in a Small Cell: Charles Taylor and the Special Court for Sierra Leone." In Lutz, Ellen L. and Caitlin Reiger (eds.), Prosecuting Heads of State. Cambridge, UK: Cambridge University Press. Pp. 205-232.

Thompson, Mark R. 1998. "The Marcos Regime in the Philippines." In Chehabi, H. E. and Juan J. Linz (eds.), Sultanistic Regimes. Baltimore, MD: Johns Hopkins University Press. Pp. 206-229.

Tomz, Michael, Gary King, and Langche Zeng. 2003. "ReLogit: Rare Events Logistic Regression." Journal of Statistical Software 8(2): 246-47.

Weeks, Jessica L. P. 2014. Dictators at War and Peace. Ithaca, NY: Cornell University Press.

Wright, Joseph, and Abel Escribà-Folch. 2012. "Authoritarian Institutions and Regime Survival: Transitions to Democracy and Subsequent Authoritarian Regimes." British Journal of Political Science 42(2): 283-309. 


\section{Biographical Statements}

Abel Escribà-Folch (abel.escriba@upf.edu) is an associate professor in the Department of Political and Social Sciences at the Universitat Pompeu Fabra, Barcelona, Spain.

Daniel Krcmaric (daniel.krcmaric@northwestern.edu) is an assistant professor in the Department of Political Science at Northwestern University, Evanston, IL, 60208. 


\section{Tables and Figures}

Figure 1: The exile destinations of dictators

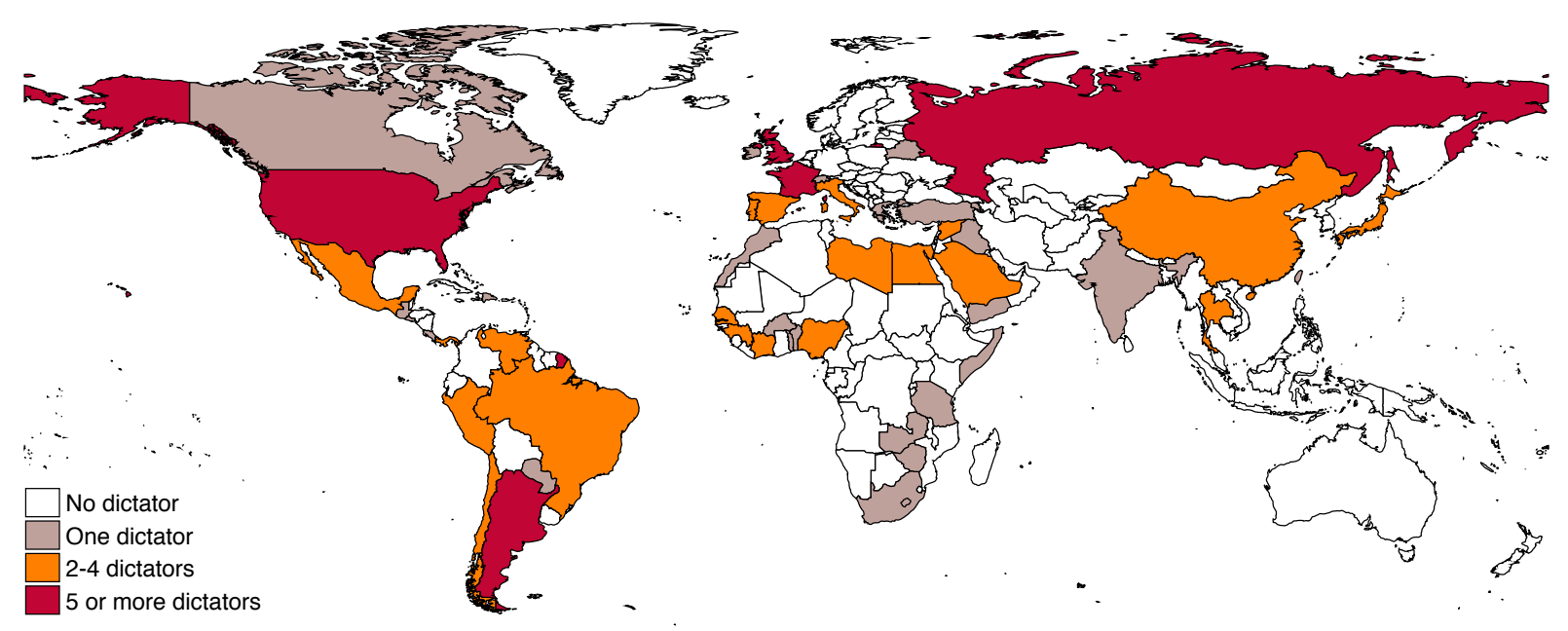


Table 1: Logit models of dictators' exile destinations

\begin{tabular}{|c|c|c|c|c|}
\hline & (1) & $\overline{(2)}$ & $(3)$ & $(4)$ \\
\hline \multicolumn{5}{|l|}{ Transnational relations } \\
\hline \multirow[t]{2}{*}{ Alliance } & $1.62^{* *}$ & $1.28^{* *}$ & $1.14^{* *}$ & $1.10^{* *}$ \\
\hline & $(0.30)$ & $(0.29)$ & $(0.27)$ & $(0.25)$ \\
\hline \multirow[t]{2}{*}{ Colony } & $4.06^{* *}$ & $3.02^{* *}$ & $2.61^{* *}$ & $2.66^{* *}$ \\
\hline & $(0.38)$ & $(0.42)$ & $(0.41)$ & $(0.43)$ \\
\hline \multirow[t]{2}{*}{ Trade interdependence } & & $0.29^{* *}$ & $0.20^{* *}$ & $0.18^{* *}$ \\
\hline & & $(0.055)$ & $(0.056)$ & $(0.056)$ \\
\hline \multicolumn{5}{|l|}{ Distance } \\
\hline \multirow[t]{2}{*}{$\overline{\text { Distance }}$} & $-0.71^{* *}$ & $-0.58^{* *}$ & $-0.75^{* *}$ & $-0.80^{* *}$ \\
\hline & $(0.11)$ & $(0.11)$ & $(0.11)$ & $(0.11)$ \\
\hline \multicolumn{5}{|l|}{ Destination characteristics } \\
\hline \multirow[t]{2}{*}{ Major power } & & & $1.32^{* *}$ & $1.32^{* *}$ \\
\hline & & & $(0.33)$ & $(0.33)$ \\
\hline \multirow[t]{2}{*}{ Democracy } & & & $-0.51^{*}$ & \\
\hline & & & $(0.21)$ & \\
\hline \multirow[t]{2}{*}{ Dictator previously hosted } & & & $0.61^{*}$ & $0.45^{+}$ \\
\hline & & & $(0.26)$ & $(0.25)$ \\
\hline \multirow[t]{2}{*}{ ICC member } & & & -0.64 & -0.62 \\
\hline & & & $(0.48)$ & $(0.50)$ \\
\hline \multirow[t]{2}{*}{ Civil war } & & & $-0.88^{*}$ & $-0.94^{* *}$ \\
\hline & & & $(0.37)$ & $(0.35)$ \\
\hline \multirow[t]{2}{*}{ Interstate war } & & & -0.14 & -0.13 \\
\hline & & & $(0.46)$ & $(0.47)$ \\
\hline \multirow[t]{2}{*}{ Personalist regime } & & & & -0.17 \\
\hline & & & & $(0.45)$ \\
\hline \multirow[t]{2}{*}{ Military regime } & & & & $0.80^{*}$ \\
\hline & & & & $(0.37)$ \\
\hline \multirow[t]{2}{*}{ Party-based regime } & & & & $0.41^{+}$ \\
\hline & & & & $(0.23)$ \\
\hline \multirow[t]{2}{*}{ Monarchy } & & & & -0.13 \\
\hline & & & & $(0.62)$ \\
\hline \multirow[t]{2}{*}{ Constant } & 0.033 & -1.11 & 0.36 & 0.52 \\
\hline & $(0.89)$ & $(0.99)$ & $(0.86)$ & $(0.89)$ \\
\hline$N$ & 13093 & 8922 & 8832 & 7987 \\
\hline$A I C$ & 910.5 & 809.5 & 789.5 & 771.6 \\
\hline$B I C$ & 940.4 & 845.0 & 867.4 & 869.4 \\
\hline
\end{tabular}


Figure 2: First difference estimates

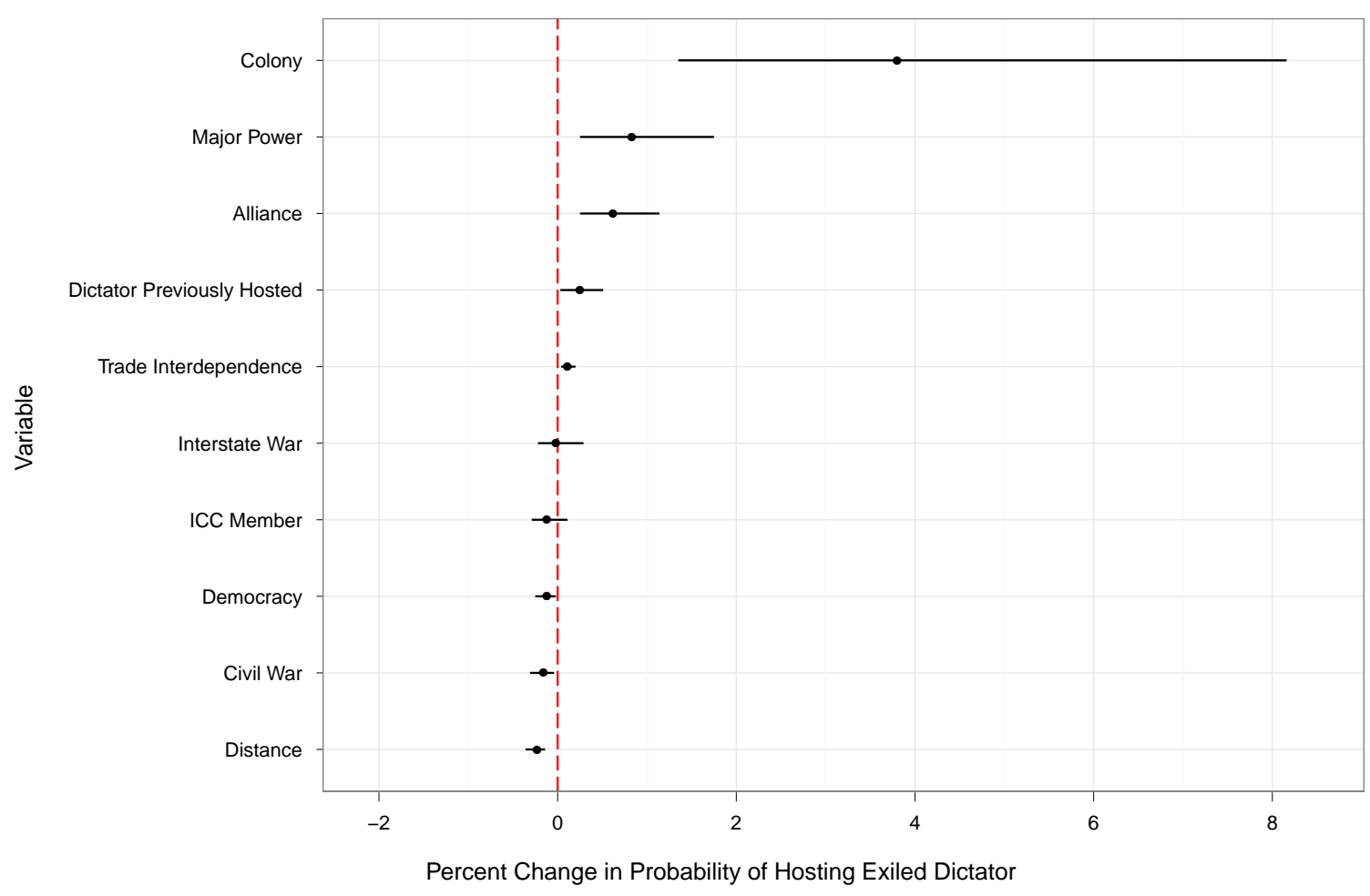


Figure 3: Exiled dictators over time

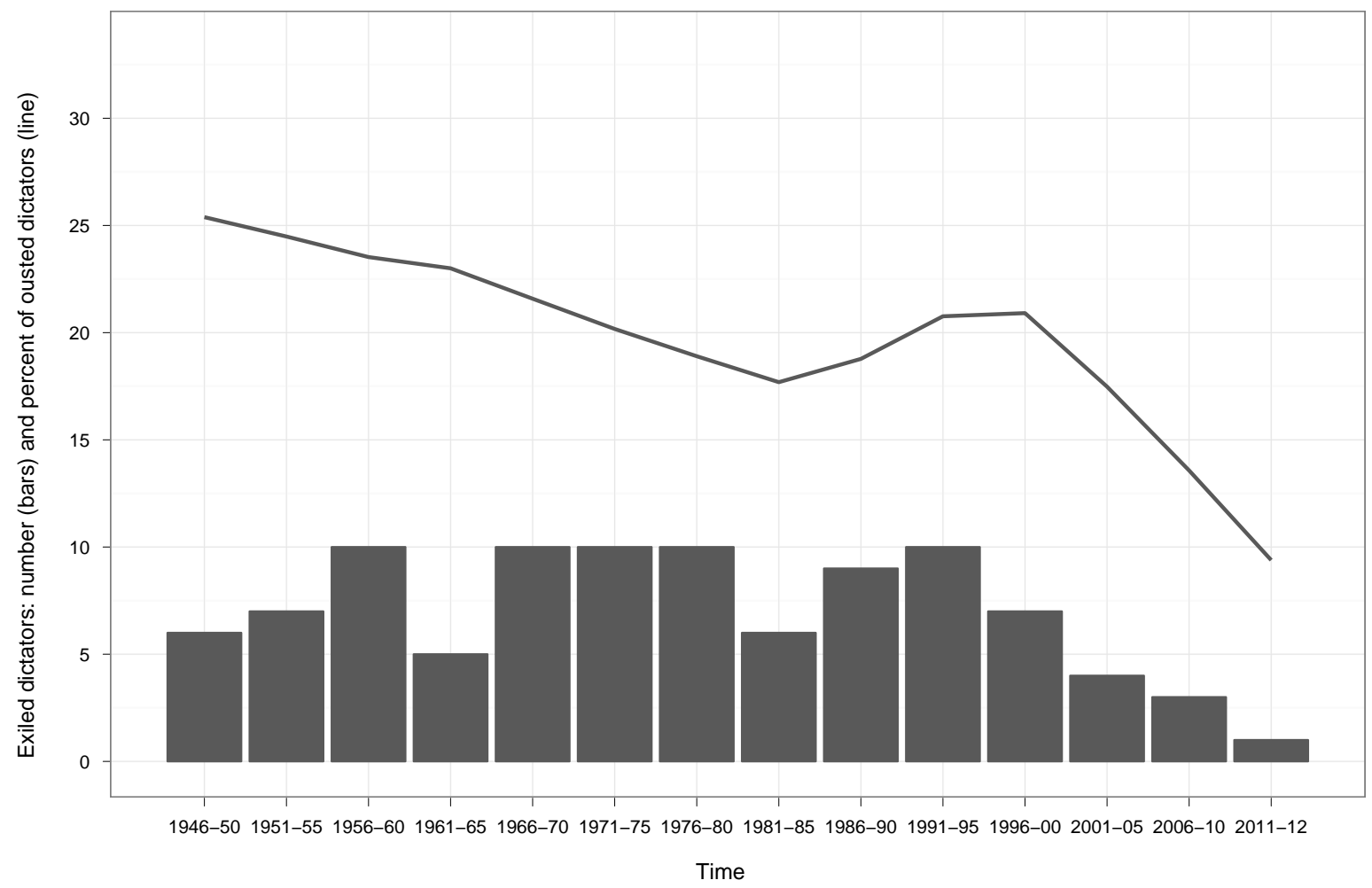

